\title{
Potential Energy Savings from Aquifer Thermal Energy Storage
}

July 1988

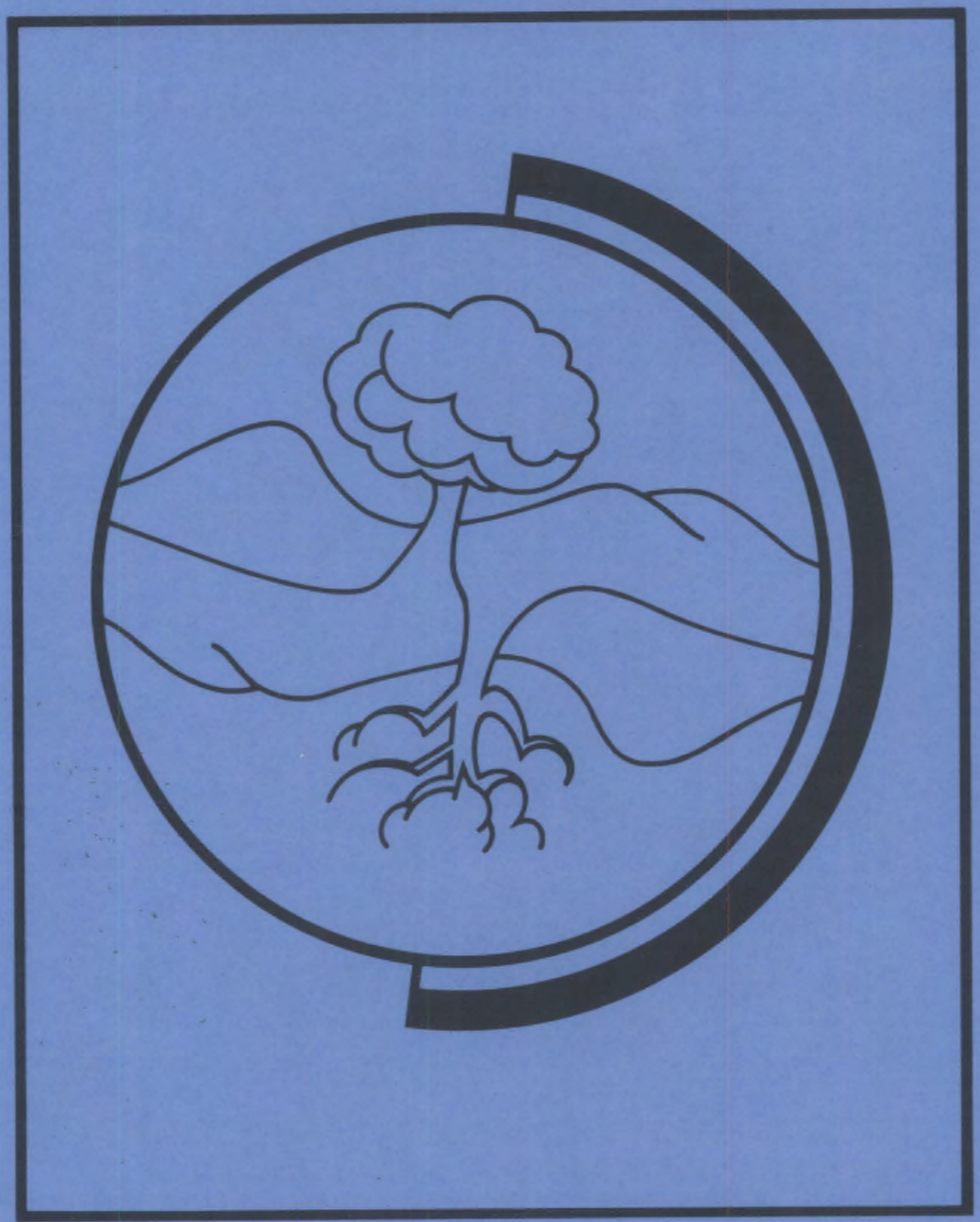

Prepared for the U.S. Department of Energy under Contract DE-AC06-76RLO 1830

Pacific Northwest Laboratory Operated for the U.S. Department of Energy by Battelle Memorial Institute 


\section{DISCLAIMER}

This report was prepared as an account of work sponsored by an agency of the United States Government. Neither the United States Government nor any agency thereof, nor Battelle Memorial Institute, nor any or their employees, makes any warranty, expressed or implied, or assumes any legal liability or responsibility for the accuracy, completeness, or usefulness of any information, apparatus, product, or process disclosed, or represents that its use would not infringe privately owned rights. Reference herein to any specific commercial product, process, or service by trade name, trademark, manufacturer, or otherwise does not necessarily constitute or imply its endorsement, recommendation, or favoring by the United States Government or any agency thereof, or Battelle Memorial Institute. The views and opinions of authors expressed herein do not necessarily state or reflect those of the United States Government or any agency thereof, or Battelle Memorial Institute.

\section{PACIFIC NORTHWEST LABORATORY operated by \\ BATTELLE MEMORIAL INSTITUTE for the \\ UNITED STATES DEPARTMENT OF ENERGY under Contract DE-AC06-76RLO 1830}

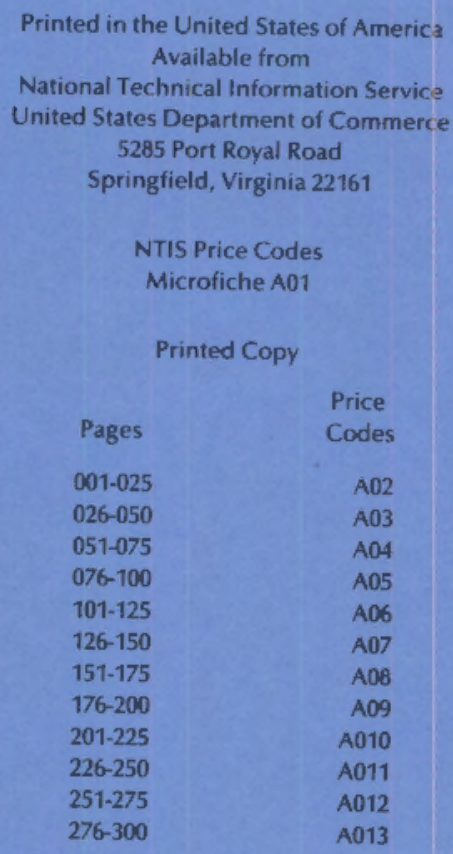


POTENTIAL ENERGY SAVINGS FROM

AQUIFER THERMAL ENERGY STORAGE

M. R. Anderson

R. 0 . Weijo

July 1988

Prepared for

the U.S. Department of Energy

under Contract DE-AC06-76RLO 1830

for the Seasonal Thermal Energy

Storage Program

Pacific Northwest Laboratory

Richland, Washington 99352 


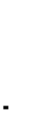




\section{PERSPECTIVE}

The use of aquifers for seasonal storage of energy has been studied by the U.S. Department of Energy through Pacific Northwest Laboratory since 1979. The direction of DOE-sponsored studies to characterize and advance this concept has remained decidedly technical, and, to a lesser extent, economic in nature. Earlier studies have indicated that the concept should be able to significantly contribute to energy conservation and favorable energy economics in many potential applications. However, no credible study had ever been completed investigating the breadth of the potential impact of this technology, nor was there any indication concerning the most favorable classes of applications. This report provides a limited examination of the potential for application of this technology in the U.S.

The estimation of the "market" that can be served by any energy technology is a challenging task. The task is doubly difficult for aquifer thermal energy storage (ATES) because of the inherent site-specific features of ATES application. The application of ATES requires not only favorable geotechnical site conditions, but also requires favorable energy availability and deliver/use conditions, especially in terms of energy supply and delivery rates, annual amounts, and proximity.

This document describes how these factors were considered in attempting to construct an accurate estimate of the potential for ATES in the U.S. As with any study, assumptions were made to keep the problem tractable while still providing reasonable accuracy. These assumptions dealt with site hydrologic suitability, as well as energy availability and demand. Furthermore, rough rules-of-thumb were used to estimate limitations in system size and cost-effectiveness, based on earlier economic studies into the effect of size on system economics. To develop a national estimate, information on random sites was aggregated to estimate total potential ATES use. The results are, therefore, reasonable estimates. They should not be interpreted as firm values, nor should the assumptions be used to assess an individual site for application of the technology. 
The results indicate there is substantial "market" for seasonal thermal energy storage (STES) systems that store abundant industrial waste heat to meet later industrial and space heating requirements. STES research can now focus on development of systems that can be most easily integrated into industrial applications.

Landis D. Kannberg, Program Manager

Seasonal Thermal Energy Storage 
Pacific Northwest Laboratory researchers developed an aggregate-level model to estimate the short-and long-term potential energy savings from using aquifer thermal energy storage (ATES) in the United States. The objectives of this effort were to 1) develop a basis from which to recomnend whether heat or chill ATES should receive future research focus and 2) determine which market sector (residential, commercial, or industrial) offers the largest potential energy savings from ATES.

Information was collected on the proportion of U.S. land area suitable for ATES applications. The economic feasibility of ATES applications was then evaluated. The potential energy savings from ATES applications was calculated. Characteristic energy use in the residential, commercial, and industrial sectors was examined, as was the relationship between waste heat production and consumption by industrial end-users.

These analyses provided the basis for two main conclusions:

- Heat ATES applications offer higher potential for energy savings than do chill ATES applications.

- The industrial sector can achieve the highest potential energy savings for the large consumption markets.

Based on these findings, it is reconmended that future ATES research and development efforts be directed toward heat ATES applications in the industrial sector. 
CONTENTS

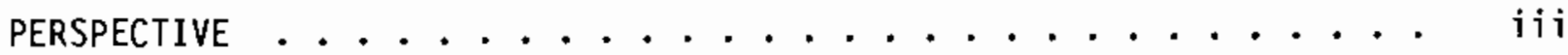

SUMMARY .......................

1.0 INTRODUCTION $\ldots \ldots \ldots \ldots \ldots \ldots \ldots . \ldots \ldots \ldots$

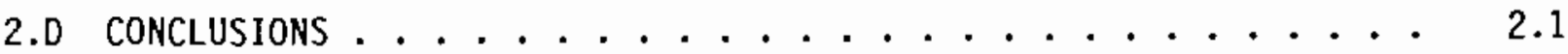

3.0 ESTIMATION MODEL $\ldots \ldots \ldots \ldots \ldots \ldots \ldots \ldots . \ldots \ldots$

3.1 PROPORTION OF U.S. SUITABLE FOR ATES . . . . . . . 3.1

3.2 ECONOMIC FEASIBILITY OF ATES SYSTEMS . . . . . . . 3.2

3.3 ESTIMATION OF ENERGY USE IN SELECTED ZIP CODE AREAS . . . 3.3

3.4 THE EFFECT OF RESIDENTIAL AND EMPLOYEE POPULATION DENSITY ON THE ECONOMIC FEASIBILITY OF ATES SYSTEMS $\ldots . . . . .3 .5$

4.0 PROPORTION OF LAND AREA SUITABLE FOR ATES . . . . . . . . 4.1

4.1 ANALYSIS CRITERIA ..................... 4.1

4.2 SITE SCREENING . . . . . . . . . . . . . 4.2

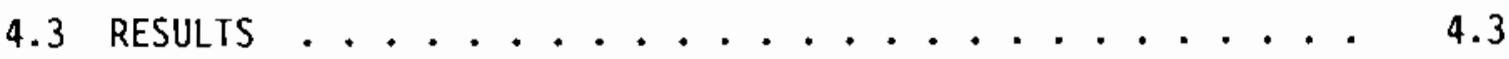

5.0 ECONOMICALLY FEASIBLE APPLICATIONS OF ATES . . . . . . 5.1

5.1 ESTIMATION OF A STRATIFIED SAMPLE OF ZIP CODES . . . . . 5.1

5.2 ESTIMATION OF RESIDENTIAL PER PERSON ENERGY CONSUMPTION . . 5.3

5.3 ESTIMATION OF COMMERCIAL PER EMPLOYEE ENERGY CONSUMPTION * 5.3

5.4 ESTIMATION OF TOTAL INDUSTRY PROCESS HEAT USE $\ldots \ldots . .$.

5.5 CONVERSION OF YEARLY CONSUMPTION TO PEAX MEGAWATT HOURS . . 5.7

5.6 CALCULATION OF PROPORTION OF U.S. ECONOMICALLY FEASIBLE FOR ATES APPLICATIONS . . . . . . . . . . . 5.7

6.0 POTENTIAL ENERGY SAVINGS FROM ATES $\ldots \ldots \ldots . \ldots . \ldots . \ldots . \ldots$

7.0 ATES MARKET DENSITY CHARACTERIZATION $\ldots \ldots \ldots . \ldots . \ldots . \ldots$

8.D ATES ENERGY USER CHARACTERIZATION . . . . . . . . . . 8.1

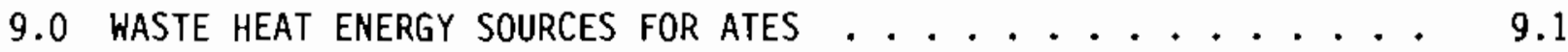

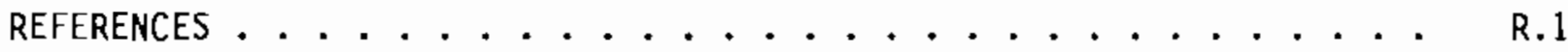
APPENDIX - SUPPLEMENTAL DATA .............. A.1

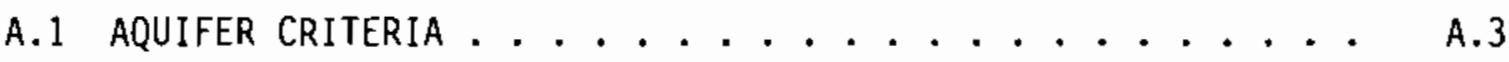

A.2 CALCULATION OF SUITABILITY OF SMALL AQUIFERS ...... A. . .

A.3 INDUSTRIAL SOURCE AND USE OF ENERGY .......... A.6 


\section{FIGURES}

3.1 Formulas for Estimating Total Heat and Chill Energy Use . . . . 3.4

5.1 U.S. Census Regions . . . . . . . . . . . . . 5.4

5.2 Proportion of U.S. Heat and Chill ATES Applications by Suitability Cut-0ffs . . . . . . . . . . . 5.8

6.1 Potential Energy Savings from ATES . . . . . . . . 6.2

8.1 Heat Energy Savings by End Use ............. 8.2

9.1 Waste Heat Energy Supply and Use . . . . . . . . . . 9.2

\section{$\underline{\text { TABLES }}$}

4.1 Suitability of 50 Potential ATES Sites . . . . . . . 4.3

5.1 Stratification Table . . . . . . . . . . 5.2

5.2 Average Annual Energy Use (MMBtu) Per Resident . . . . . . . 5.5

5.3 Average Annual Energy Use (MMBtu) Per Employee . . . . . . . 5.5

7.1 The Proportion of Heat ATES Systems of Various Megawatt Sizes that are Economically Feasible at Different Residential

Population Densities ..................... 7.2

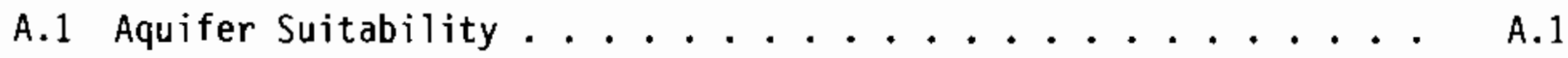

A.2 Large Systen Limiting Guidelines . . . . . . . . . A.4

A.3 Small System Limiting Guidelines . . . . . . . . A. A

A.4 Aquifer Thermal Energy Storage Annual Energy Input/Usage . . . A.7 
POTENTIAL ENERGY SAVINGS FROM AQUIFER THERMAL ENERGY STORAGE

\section{$1.0 \quad$ INTRODUCTION}

Since 1979, the Pacific Northwest Laboratory(a) has managed the Seasonal Thermal Energy Storage Program for the U.S. Department of Energy. A primary goal of that program is to develop the aquifer themal energy storage concept into a commercially viable technology for deployment to the private sector.

Aquifer thermal energy storage (ATES) appears to be an economical and widely applicable technique for resolving the imbalance between time-dependent energy supplies and thermal or electrical demands. An ATES system in its simplest form consists of a pair of ordinary water wells drilled into an aquifer. During operation, the groundwater is withdrawn from the supply well, heated (or chilled) in a heat exchanger, and then returned to the same aquifer through the storage well. The thermal energy (heat or chill) is stored in the aquifer until needed. At recovery, the storage well is pumped; the heated or chilled water is then circulated through a heat exchanger, where the stored energy is recaptured. The water is then returned to the aquifer through the supply well. The thermal energy extracted from the water can then be used for space or process heating/cooling, thereby reducing the need to generate primary energy.

Three major sources of thermal energy are available for ATES: cogenerated heat, climate-related energy, and industrial waste heat. The key to ATES effectiveness is that the energy recovered from these sources is energy that would have otherwise been wasted, generally because no demand existed for it at the time it was available. The ATES concept is attractive because it mitigates this pervasive mismatch of energy supply and demand over time (Meyer and Hauz 1980).

(a) Operated by Battelle Memorial Institute for the U.S. Department of Energy under Contract DE-ACO6-76RLO 1830. 
The ATES concept is simple and relatively efficient. However, like other energy storage technologies, ATES is subject to distribution and storage energy losses. Depending on system design and aquifer characteristics, the percentage of recoverable source energy can range as widely as $50 \%$ to $90 \%$.

In support of the Underground Energy Storage Program, a study was conducted to estimate the aggregate short- and long-term potential energy savings from ATES use in the United States. Potential savings refers to the total possible: energy saved, with no consideration of governmental, environmental, or other constraints. This study had two primary objectives. First, it sought to provide a recommendation regarding the logical emphasis for future ATES research. Second, it sought to determine which of the end markets-residential, commercial, or industrial--offers the largest energy savings from ATES implementation.

The conclusions and recommendations derived from this study are presented in Section 2. In Section 3, the overall model used to derive estimates of the potential energy savings is described. Section 4 discusses the percentage of U.S. aquifers suitable for ATES applications. In Section 5, the economic feasibility evaluation of ATES applications is documented. Calculations of the potential energy savings from ATES applications are detailed in Section 6 . In Section 7, the characteristics of energy use in the residential, commercial, and industrial sectors are examined. Possible sources of energy for feasible applications of ATES are considered in Section 8. An appendix contains detailed information in support of the methodology used in this study. 


\subsection{CONCLUSIONS}

The results of this study indicate that the potential energy savings for aquifer thermal energy storage (ATES) are concentrated in heat applications. The estimated long-term potential energy savings for heat ATES applications were from $10.57 \%$ to $2.38 \%$ of total national energy consumption. The most attainable short-term savings were in the greater than 30- to 40-MW market. This translates into 3 quads of energy, or about $3.5 \%$ of total national energy consumption.

Chill storage did not display significant energy savings in this aggregatelevel study. However, these findings do not indicate that chill-based ATES systems should be abandoned as a means of decreasing national energy consumption. Rather, chill ATES should be considered for specialized markets that are not sensitive to economies of scale.

The evaluation of end-use sectors determined that industrial end-users can achieve the highest potential energy savings for the large consumption markets. Analysis also indicated that a small number of industrial users are included in zip code areas characterized by high energy consumption. This suggests that the industrial sector is a potentially attractive entry market for efforts to commercialize ATES.

The availability of waste process heat indicates that, for the markets characterized by more than 20-MW consumption, sufficient excess waste heat al ready exists to operate heat-based ATES systems. This suggests that potential energy savings can be considered "real savings" because no additional sources of waste heat are needed to match energy consumption demands in a zip code area.

This study addressed the potential energy savings on an aggregate level for the U.S. It did not, however, try to estimate the actual market penetration of ATES. Penetration is affected by market factors such as political, economic, environmental, and institutional issues. To properly assess ATES, it is necessary to evaluate each of these factors to determine the issues affecting the acceptance of the technology. This would give further insight into the problems and benefits affecting ATES, so that market penetration efforts could be focused toward the optimum target markets. 



\subsection{ESTIMATION MODEL}

An aggregate-level model was used for this analysis because the focus was on deriving national estimates of potential energy savings. The model considered two key factors that affect the application of ATES systems for heating and cooling: the proportion of the U.S. with suitable aquifers and the economic feasibility of ATES systems. The model performs the following calculation:

\begin{tabular}{|c|c|c|c|c|c|c|}
\hline $\begin{array}{l}\text { Total } \\
\text { National } \\
\text { Heat or } \\
\text { Chill } \\
\text { Energy Use }\end{array}$ & $x$ & $\begin{array}{l}\text { Proportion } \\
\text { of U.S. } \\
\text { Land Area } \\
\text { Suitable } \\
\text { for ATES }\end{array}$ & $x$ & $\begin{array}{l}\text { Proportion of } \\
\text { Geographic } \\
\text { Units Econo- } \\
\text { mically Suit- } \\
\text { able for ATES }\end{array}$ & $=$ & $\begin{array}{l}\text { Potential } \\
\text { Energy } \\
\text { Savings from } \\
\text { Heat or } \\
\text { Chill ATES }\end{array}$ \\
\hline
\end{tabular}

\subsection{PROPORTION OF U.S. SUITABLE FOR ATES}

The first factor affecting the potential of ATES is the dependence on suitable aquifers. Several natural conditions must be present at an aquifer site before it can qualify for ATES. These conditions include the productivity of an aquifer and the presence or absence of primary and secondary porosity.

We estimated the proportion of aquifers appropriate for ATES by selecting a random sample of zip code areas nationally and then determining what proportion met requirements for ATES aquifer suitability. Zip code areas were chosen over other geographic areas, such as metropolitan statistical areas and counties, primarily because they were considered sufficiently small for ATES land area requirements. Current ATES systems are restricted to relatively small serviceable areas because of the energy that is lost when it is distributed over large areas from a single source. A second important advantage in using zip code areas is that detailed secondary information can be obtained on them. Commercial market research firms offer detailed demographic and economic information on zip code areas. This type of data is used by the private sector for marketing strategies. 


\subsection{ECONOMIC FEASIBILITY OF ATES SYSTEMS}

The second factor affecting the potential of ATES is economic feasibility. Most of the costs associated with developing ATES systems are fixed costs. Generally, high fixed-cost systems can be cost competitive only by using the economies of scale associated with high energy consumption.

If the economic feasibility conducted in this analysis had been sitespecific, a variety of cost factors would have been considered in the analysis. These factors would have included the purchase price for thermal energy, exploration and well drilling costs, capital equipment costs, operation and maintenance costs, and interest rates available for loans. Technical characteristics of the aquifer and its supply and distribution system also would have been considered as influences on ATES system economics.

However, for this study, only an aggregate-level analysis was conducted. This economic analysis was based on the findings of Reilly, Brown, and Huber (1981) and Brown (1983), who developed estimates of aquifer system size requirements for heat and chill sources, respectively. Those studies found that significant economies of scale are available for point-demand systems of approximately $10 \mathrm{MW}$ or larger.

In the analysis conducted for this study, we determined the proportion of total zip code areas that use heat or chill beyond a certain cost-effective energy consumption level (expressed in megawatts). This was accomplished by selecting a representative sample of U.S. zip code areas and determining their total heat and chill energy consumption for commercial and residential space heating/cooling and industrial process heat. Each area was then evaluated on whether it was above or below these cost-effective energy consumption levels. The proportion of those falling above the minimum range was computed and used to estimate the total number of U.S. zip code areas that could use ATES systems cost effectively.

A range of system sizes was studied to evaluate the sensitivity of required system size on ATES energy savings. This range was chosen because of the many varying factors that influence when an ATES system will become cost 
effective. Energy savings could then be calculated over a complete range of cut-offs, thereby providing a "what if" analysis. Also, short- and long-term energy savings scenarios could then be developed. Instead of providing only one short-term and one long-term estimate of energy savings, the megawatt sliding scale was used. This scale provides a more complete range of shortand long-term energy savings estimates for various sizes of ATES systems.

Total U.S. energy savings from ATES can be calculated from the following formula, which is derived from the model presented above:

\begin{tabular}{|c|c|c|c|c|c|c|c|}
\hline $\begin{array}{l}\text { Total } \\
\text { Potential } \\
\text { Energy } \\
\text { Savings }\end{array}$ & $=$ & $\begin{array}{l}\text { Proportion } \\
\text { of Zip Code } \\
\text { Areas Both } \\
\text { Geologically/ } \\
\text { Economically } \\
\text { Suitable for } \\
\text { Heat Storage }\end{array}$ & $\mathbf{x}$ & $\begin{array}{l}\text { Total Space } \\
\text { and Process } \\
\text { Heating in } \\
\text { the U.S. }\end{array}$ & + & $\begin{array}{l}\text { Proportion } \\
\text { of Zip Code } \\
\text { Areas Both } \\
\text { Geologically/ } \\
\text { Economically } \\
\text { Suitable for } \\
\text { Chill Storage }\end{array}$ & $\begin{array}{l}\text { Total Space } \\
\text { Cooling } \\
\text { in the U.S. }\end{array}$ \\
\hline
\end{tabular}

\subsection{ESTIMATION OF ENERGY USE IN SELECTED ZIP CODE AREAS}

A necessary input to the formula presented above is an estimation of the proportion of zip code areas suitable for heat or chill storage. Figure 3.1 describes the formulas used to estimate the total energy used within a zip code area. These formulas show the three important components in these energy consumption estimates:

1. energy use by residents - To estimate energy use by residents, a regional estimate was developed of average per person energy use for heat and chill. Residential energy use in each zip code area was obtained by multiplying the average energy use per person by the number of individuals who live in that area.

2. energy use by employees - The basic method for estimating energy use by employees was similar to that described above. A regional estimate of average per employee energy use was developed for heat and chill. Employee energy use in each zip code area was then the average energy use per employee multiplied by the number of individuals who work in that zip code area. 


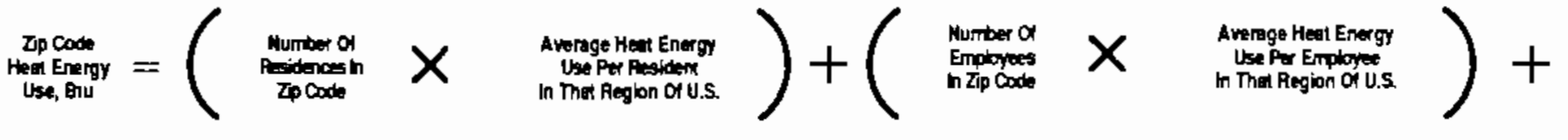

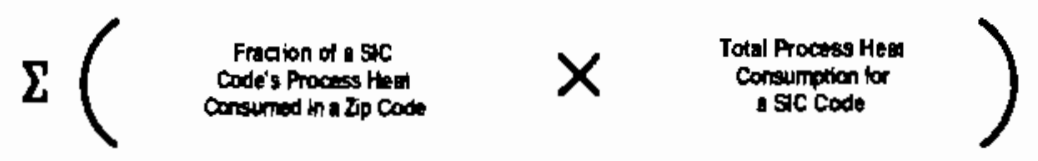

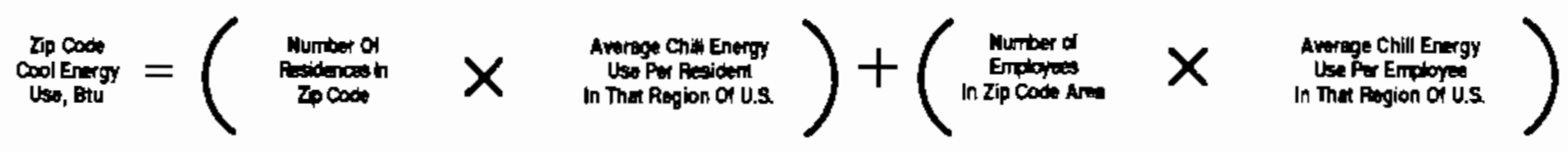

FIGURE 3.1. Formulas for Estimating Total Heat and Chill Energy Use 
3. industrial process energy use - The estimate of industrial process heat was determined from a list of individual Standard Industrial Classification (SIC) codes within each zip code area. Industrial process energy consumption was calculated as the proportion of firms from an SIC code (on a national basis) located within a zip code area multiplied by that SIC code's total national consumption of process heat.

\subsection{THE EFFECT OF RESIDENTIAL AND EMPLOYEE POPULATION DENSITY ON THE ECONOMIC FEASIBILITY OF ATES SYSTEMS}

A fundamental factor affecting the economic feasibility of ATES systems is the residential and employee population density within a zip code area. High population density minimizes the required capital expenditures on underground piping and increases the number of available users to the system.

To evaluate the effect of population density on ATES system feasibility, a stratified sampling procedure was employed in this study. The random sample of $z$ ip codes selected for this study were stratified on two variables. The first variable split residential population into two categories: $<6500$ and $>6500$ residents per square mile. The second variable split employee population density into three categories: 0 to 2000,2000 to 6500 , and greater than 6500 employees per square mile.

The major data required to complete this study included a complete zip code list with the following information on each zip: residential population, employment population, area in square miles, and a complete list of SIC codes with the proportion of firms (on a national basis) that are located in that $z$ ip code area.

A commercial market research firm, Market Statistics, was employed to provide the data described above. Like many data companies, Market Statistics has census information grouped by zip codes with the area in square miles given. This company, however, also has SIC code data for individual zip codes. 



\subsection{PROPORTION OF LAND AREA SUITABLE FOR ATES}

To detemine the proportion of U.S. land area suitable for ATES applications, a simple random sample of zip codes was selected. This sample was then analyzed to determine what proportion were suitable for either chill or heat, large or small ATES applications. These proportions would then be used as the national proportions of land area suitability.

The simple random sample was determined by using a nomal random number generator, which randomly selected 50 zip codes from the complete data base of 40,000 zip codes in the U.S. The analysis conducted on each randomly selected zip code used information available from the Water Supply Papers and Hydrologic Investigations Atlases published by the U.S. Geological Survey. Access to these documents was obtained through the University Washington, Government Publications Depository at the University of Idaho library. In addition, for specific questions, phone calls were made to several local U.S. Geological Survey offices.

\subsection{ANALYSIS CRITERIA}

Several aquifer characteristics must be evaluated at any potential ATES site. These characteristics and the appropriate ranges of values for both large and small systems have been identified by Century West Engineering Corporation (1981, Table 1). The list consists primarily of hydraulic properties that measure the productivity of aquifer materials. The properties listed include aquifer depth and thickness, typical water production yields for wells drilled into the aquifer, and aquifer material coefficients of transmissivity and porosity.

Transmissivity is always directly proportional to thickness and well yield as well as to porosity for most earth materials except clay. Consequently, transmissivity is the most important parameter. Intergranular porosity, such as that found in a sand aquifer, is best because the uniform properties of the aquifer medium allow for more controlled, predictable injection and recovery of thermal waters. Crystalline rock aquifers commonly contain 
irregularly distributed fracture porosity and usually do not yield sufficient quantities of water for ATES purposes. Carbonate rocks commonly exhibit solution porosity and are less desirable because the solution cavities that can contain most of the water are often highly irregular. Transmissivity in such aquifers can range widely with the result that controlled, predictable injection and recovery of thermal waters is unlikely. Depth of the aquifer becomes important for high-temperature ATES because of overburden requirements needed to maintain sufficient pressure to prevent flashing of water at temperatures greater than $100^{\circ} \mathrm{C}$.

\subsection{SITE SCREENING}

The 50 selected sites were screened using the above criteria. The first step in the screening process was to determine whether the given site had aquifers sufficiently productive to support some forn of ATES. The lithology of the aquifer material provided the initial estimate of productivity. The ideal situation for ATES development is a relatively thick sand aquifer. These types of aquifers are commonly found along the Atlantic and Gulf Coastal Plains and irregularly throughout the remainder of the U.S. Such sites were given a preliminary favorable rating. Crystalline rock aquifers rarely produce more water than $20 \mathrm{gpm}$; thus, sites with these aquifers were given a preliminary unfavorable rating.

The aquifers at each site were then screened for sufficient transmissivit, thickness, and well yield. A sufficient number of wells have been drilled around the U.S. to delineate the extent and thickness of major aquifers. The aquifers have been tested to determine their transmissivities and well yields. These data have been reported for most areas of the country. The well data also allowed determination of whether the overburden was sufficiently impermeable to confine the aquifer.

Two important parameters were not considered in the screening process. These are the regional groundwater gradient and the thermal diffusivity of the aquifer system. The groundwater velocity is directly proportional to the groundwater gradient; thermal diffusivity describes the ability of the aquifer 
to dissipate heat. Large groundwater gradients would cause extreme movement of injected thermal waters away from recovery wells; the thermally stored energy would be unrecoverable. Aquifers having high thermal diffusivity would allow excessive dissipation of heat. The recovery of thermal energy would be reduced. Both of these parameters should be minimized.

The quality of the information varied from site to site. The information tended to be on varying scales from state to county to site specific. The information was sufficient to identify unfavorable sites and to give a reasonable indication of the size of system that a particular site might support. This level of information obtained for this report is sufficient for the current reconnaissance-level study. The procedures leading to the actual construction of an ATES facility would require intensive site characterization that would most likely include drilling test wells and conducting aquifer tests to determine the subsurface lithologies, aquifer transmissivity, the regional groundwater gradient, and other parameters.

\subsection{RESULTS}

Table 4.1 summarizes the results of the evaluation of the 50 zip code areas. Of the 50 sites, $14(28 \%)$ were found to be unsuitable for any form of ATES. Twenty-two sites (44\%) were found to be suitable for both large- and small-scale ATES. Fourteen sites (28\%) were found suitable for only small-scale ATES; of these, four (29\%) were suitable for only chill and low-heat storage because of insufficient overburden for high heat conditions.

\section{TABLE 4.1. Suitability of 50 Potential ATES Sites}

$\begin{array}{ccc}\text { Unsuitable }_{14 / 50} & \frac{\text { Small-Scale Only }}{(a)} & \frac{\text { Large- and Small-Scale }}{(\text { b) }} \\ (28 \%) & 14 / 50 & 22 / 50 \\ (28 \%) & (44 \%)\end{array}$

(a) A small-scale ATES site can support a <10-MW peak demand.

(b) Large-scale aquifers can also be used for small-scale applications of ATES. 
. 


\subsection{ECONOMICALLY FEASIBLE APPLICATIONS OF ATES}

This section describes the methods used to calculate the economic feasibility of ATES.

\subsection{ESTIMATION OF A STRATIFIEO SAMPLE OF ZIP CODES}

To properly sample the U.S. for estimating the suitable proportion of economically feasible zip code areas, a stratified sampling methodology was employed. Stratified sampling is a two-step procedure that divides the parent population into mutually exclusive and collectively exhaustive subgroups or sample frames. A simple, random sample of each sample frame is then drawn.

In this study, subgroups were developed from ranges of residential and employment population densities. The residential stratum range was split at 6500 persons per square mile, which is considered typical for a cost-effective district heating system. The employment ranges were determined by looking at a plot of the frequency of employment densities within zip code areas to identify where the inflection point (i.e, change in pitch) occurred. The inflection occurred at approximately 2000 employees per square mile.

Using both of these densities, a matrix was put together that broke the nation's zip code areas into six mutually exclusive sample frames. The final frames are:

1. Employee Density $>6500$ and Residential Density $>6500$

2. Employee Density $>6500$ and Residential Density $<6500$

3. Employee Density $<6500$ and $>2000$, and Residential Density $>6500$

4. Employee Density $<6500$ and $>2000$, and Residential Density $<6500$

5. Employee Density $<2000$ and Residential Density $>6500$

6. Employee Density $<2000$ and Residential Density $<6500$.

A sample of 30 zip codes was selected from each of the subgroups described above, for a total of 180 zip codes. By drawing 30 zip codes from each subgroup, the Central Limit Theorem applies, which states that as the sample size becomes large (i.e., $\geq 30$ observations), the samples drawn provide accurate and unbiased estimates of the population from which they were taken. Thus, the 
estimates derived from these samples can be extrapolated to the population from which they were drawn.

The sizes of the sampling frames for each stratified category are presented in Table 5.1. Each cell has a group of four descriptors that can be used to study the makeup of each of the sample frames. The first descriptor given indicates the total number of zip codes that match the stratifying densities. The resident and employment descriptors represent the actual sum of the residential and employment populations of each zip code area. The RESPROP and EMPPROP designations are the proportions of each of the Residents and Employees descriptors for each group over their respective totals (i.e., added

TABLE 5.1. Stratification Table

\begin{tabular}{|c|c|c|c|}
\hline Employment Density & Total & $>6500$ & $<6500$ \\
\hline \multirow[t]{5}{*}{$>6500$} & Frequency & 232 zip codes & 182 zip codes \\
\hline & Residents & $5,796,338$ & 897,529 \\
\hline & Employees & $5,572,629$ & $4,535,026$ \\
\hline & RESPROP (a) & 0.023 & 0.004 \\
\hline & $\operatorname{EMPPROP}(\mathrm{b})$ & 0.084 & 0.069 \\
\hline \multirow[t]{5}{*}{$<6500$ and $>2000$} & Frequency & 545 & 578 \\
\hline & Residents & $18,107,743$ & $11,981,425$ \\
\hline & Employees & $5,579,703$ & $9,582,596$ \\
\hline & RESPROP & 0.0727 & 0.048 \\
\hline & EMPPROP & 0.085 & 0.145 \\
\hline \multirow[t]{5}{*}{$<2000$} & Frequency & 424 & $37,000(c)$ \\
\hline & Residents & $12,670,747$ & $200,000,000(c)$ \\
\hline & Emp loyees & $1,760,203$ & $39,000,000(\mathrm{c})$ \\
\hline & RESPROP & 0.051 & 0.802 \\
\hline & EMPPROP & 0.027 & 0.591 \\
\hline
\end{tabular}

\footnotetext{
(a) RESPROP $=$ Residents $/$ Total Population (i.e., cells 1 through $6=$ $\approx 249,000,000$ residents).

(b) EMPPROP $=$ Employees/Total Employees (i.e., cells 1 through $6=$ $\approx 66,000,000$ emp loyees).

(c) Estimates based on cell 1-5 totals and population figures found in the Statistical Abstract of the United States (U.S. Department of Commerce 1986).
} 
all six). Using all these descriptors, it should be evident that the $>6500$ employment and $<6500$ residential cell represents the smallest sampling frame with only 182 zip codes and only 0.004 and 0.069 of total employees and population, respectively, in the U.S.

\subsection{ESTIMATION OF RESIDENTIAL PER PERSON ENERGY CONSUMPTION}

To determine the energy consumption for space heating and cooling for the residential population of each zip code area, an estimate of residential per person energy consumption was multiplied by each residential population within a zip code. The estimate of residential per person energy consumption was calculated by taking the proportion of each fuel type (i.e., electricity, gas, liquid propane gas, and oil/kerosene) by census region used for residential space heating and cooling in 1984 (Latta 1983) and multiplying these values by the current consumption of each fuel by census region for 1985 (Energy Information Administration 1985).

Four census regions (see Figure 5.1) were used in this analysis to allow for regional variation in heating and cooling. Estimates for the per person energy consumption for space heating and cooling in the four census regions are shown in Table 5.2.

\subsection{ESTIMATION OF COMMERCIAL PER EMPLOYEE ENERGY CONSUMPTION}

Table 5.3 gives the calculations of the comnercial and industrial energy consumption for heat and chill space heating. Like the residential calculations, the end-use consumption for the comnercial sector was determined by multiplying the employment population by some typical regional value for the consumption of space heat and chill energy.

Energy consumption per employee by fuel type for heating and cooling was derived from two sources. The first is the nonresidential building consumption surveys (NBECS) conducted by the Energy Information Administration (EIA) in 1979 and in 1983 (Energy Information Administration 1979, 1983). The second source is the data base underlying the commercial sector energy model (COMMEND) developed by the Electric Power Research Institute (EPRI) (Resource Dynamics Corporation 1986). 


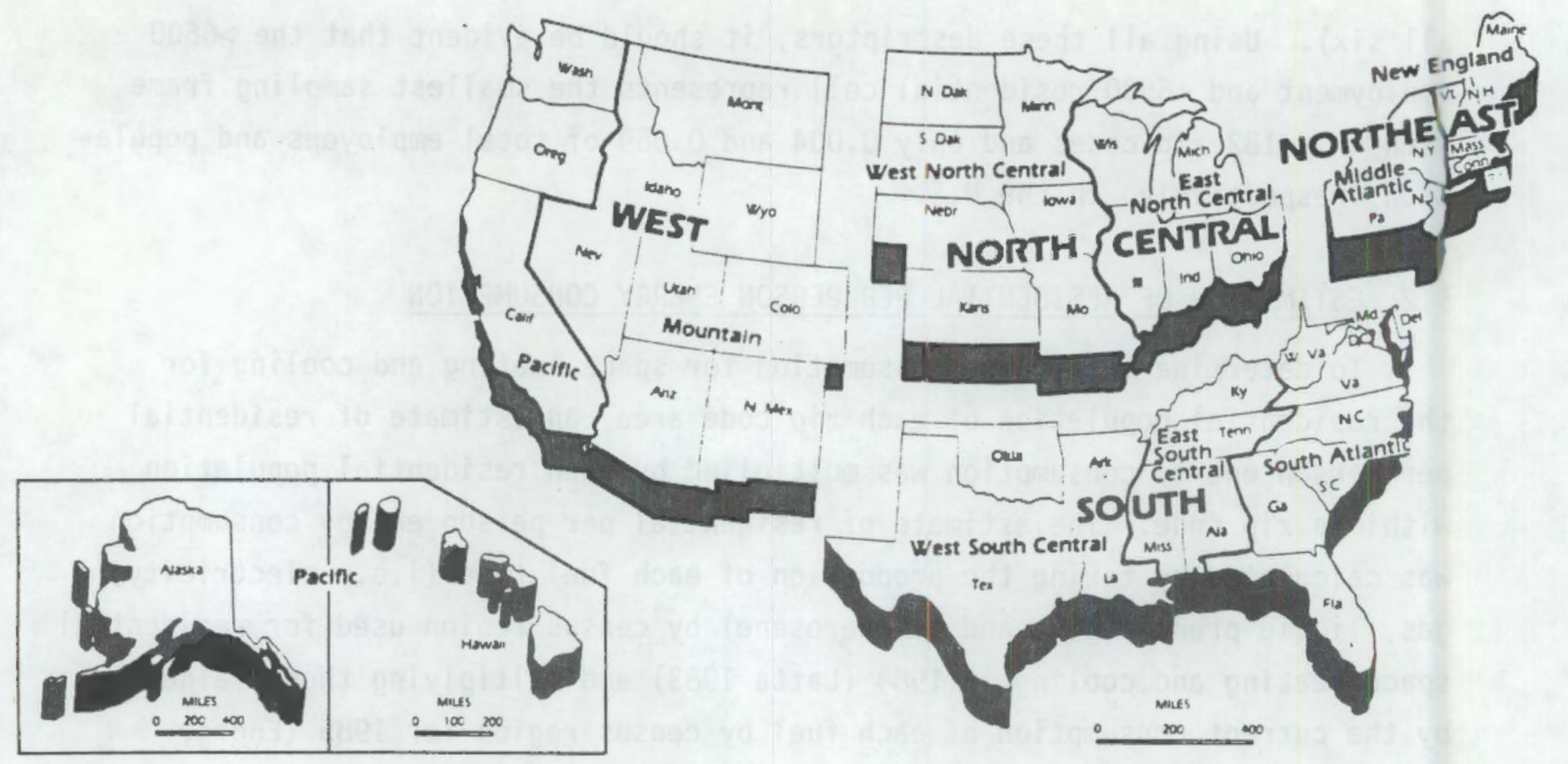

FIGURE 5.1. U.S. Census Regions

The estimates were developed by first using NBECS to develop estimates of energy per employee by both fuel type and census region. The EPRI information was then used in conjunction with other NBECS data to allocate these totals by major end use. The EPRI report provided estimates of energy intensity (energy per square foot) by end use, fuel type, and building types, as well as information on the stock of floor space by building type. The EIA surveys provided the percentage of floor space using a specific fuel for heating or cooling. This information was combined to produce an estimated share of total fuel used by census region for heating and cooling. These shares were then multiplied by the total energy per employee figures taken from the 1983 NBECS.

Total employment instead of only commercial employment was used as the multiplier in developing estimates of space heating and cooling by zip code area, because the available data for industrial consumption estimates were limited to only process heat consumption, thus omitting space heating and cooling for employees. 
TABLE 5.2. Average Annual Energy Use (MMBtu) Per Resident

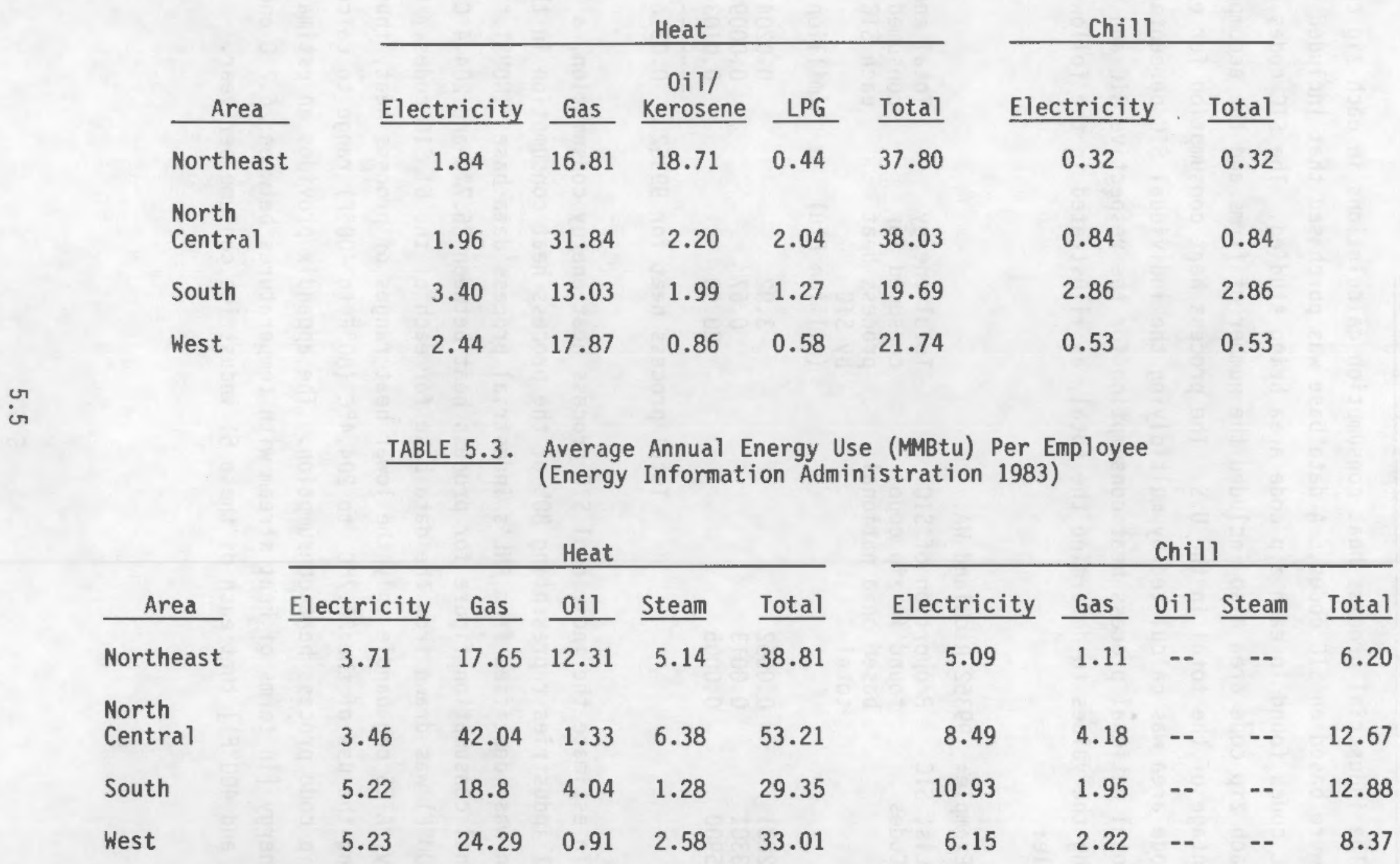




\subsection{ESTIMATION OF TOTAL INDUSTRY PROCESS HEAT USE}

The industrial process heat consumption calculations in each zip code area were based on SIC codes. A data base was purchased that included listing of SIC codes found in each zip code area being studied. The SIC codes given for each zip code area also included the number of firms and the accompanying percentage of the total in the U.S. The process heat consumption for each zip code area was calculated by multiplying the individual SIC percentages by the total national process heat consumption for the respective SIC and then summing the values to determine the total, as illustrated in the following example:

$\begin{array}{lccc}\begin{array}{l}\text { Example: } \\ \text { List SIC }\end{array} & \begin{array}{c}99352 \text { Richland WA. } \\ \text { Proportion of SIC } \\ \text { found in zip code } \\ \text { based on a national } \\ \text { total }\end{array} & \begin{array}{l}\text { Total energy } \\ \text { consumed for } \\ \text { process heat } \\ \text { by SIC } \\ \text { (million Btu) }\end{array} & \begin{array}{l}\text { Total energy } \\ \text { consumed for } \\ \text { each SIC }\end{array} \\ & & 3.92 & \text { (million Btu) } \\ 2231 & 0.0052 & 0.67 & 0.0204 \\ 3301 & 0.0013 & 20.50 & 0.0009 \\ 5900 & 0.0005 & 0.0103 & -0.0316\end{array}$

To estimate the individual SIC process heat energy consumption, a list of the 61 industries representing $80 \%$ of the process heat consumption in the nation was identified from PNL's industrial process data base "INDUST." A national consumption figure for process heat between $26.7^{\circ} \mathrm{C}$ and $204.4^{\circ} \mathrm{C}\left(80^{\circ} \mathrm{F}\right.$ and $400^{\circ} \mathrm{F}$ ) was drawn from the data base for each of the 61 SIC codes. Currently, ATES can handle only the lower heat ranges of process heat, thus justifying the use of the $26.7^{\circ} \mathrm{C}$ to $204.4^{\circ} \mathrm{C}\left(80^{\circ} \mathrm{F}\right.$ to $\left.400^{\circ} \mathrm{F}\right)$ range to calculate the zip code process heat consumption. The appendix provides an estimate of the energy [in terms of heat stream with temperatures between $26.7^{\circ} \mathrm{C}$ and $204.4^{\circ} \mathrm{C}$ $\left(80^{\circ} \mathrm{F}\right.$ and $\left.\left.400^{\circ} \mathrm{F}\right)\right]$ that each of these 61 industries consume per year. 


\subsection{CONVERSION OF YEARLY CONSUMPTION TO PEAK MEGAWATT HOURS}

The calculations of energy consumption by each of the end-use sectors for space heating and cooling and process heat were all based on British thermal units consumed per year. To use the megawatt consumption ranges outlined earlier for determining economic feasibility, it was necessary to convert the yearly British thermal unit values to peak megawatt-hours.

The conversion calculation first summed the individual zip code area annual energy consumption by heat and chill for each of the end uses (residential, commercial, industrial). These values were then converted to peak hourly energy by assuming an annual load factor of 1/3 (Reilly, Brown, and Huber 1981). Load factor is defined as the ratio of average annual hourly demand to peak hourly demand, and is one of the most important parameters affecting the unit cost of energy. Equation (5.1) defines the relationship between annual energy consumption (Btu/yr) and peak energy consumption (MW):

$$
M W=B t u / y r \times 1 \mathrm{yr} / 8760 \mathrm{~h} \times(1 / 3) \times 1 \mathrm{MW} / 3,413,000 \mathrm{Btu} / \mathrm{h}
$$

\subsection{CALCULATION OF PROPORTION OF U.S. ECONOMICALLY FEASIBLE FOR ATES APPLICATIONS}

The calculation of the proportion of the U.S. that is economically feasible for heat and chill ATES applications was based on a range of peak megawatt-hour cut-offs. These ranges are used because of the ambiguity associated with economic feasibility with respect to overall consumption of energy. The exact consumption necessary for a cost-effective ATES system has never been determined. The use of megawatt ranges approaches this problem by using each as a cost-effective cut-off. Subsequently, the proportions of the U.S. that are economically suitable for ATES are calculated for all the ranges. The ranges used were $>0,>10,>20,>30,>40,>50$, and $>100$ peak megawatt-hours.

To determine the proportion for each range, a count was taken from each of the 6 subsamples of 30 zip codes for both heat and chill consumption. This count gave the number that met the individual range criterion. The counts for both heat and chill were then weighted (i.e., multiplier that indicates the 
relative importance of each quantity's contribution to the average) and averaged. This was done by multiplying them by the sum of residential and employment populations of their respective sample (i.e., 30 zip codes in each group) and dividing by the total residential and employment populations for the 180 zip codes. A weighted average was calculated, thereby producing the proportion of U.S. zip code areas suitable for ATES using the range and type of storage in question. The final proportions of the U.S. economically suitable for ATES heat and chill applications using the respective cut-offs are shown in Figure 5.2. As is evident, the economically feasible proportion of the U.S. for heat is shown as having a decreasing value as megawatt cut-offs are increased. The economically feasible proportions for the chill-based ATES systems are nonexistent above $10 \mathrm{MW}$.

Percentage of the

U.S. Economically

Suitable for ATES

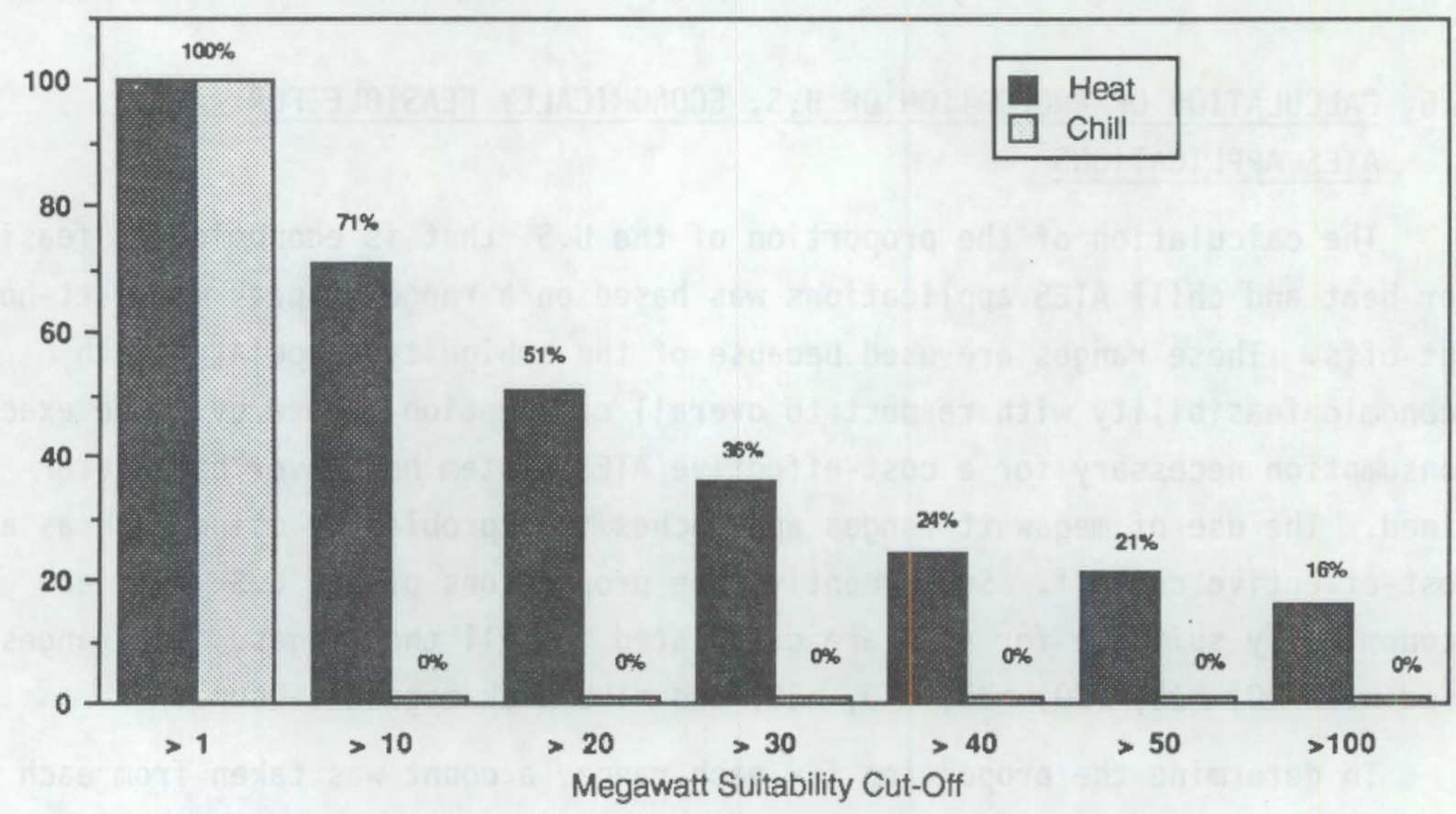

FIGURE 5.2. Proportion of U.S. Heat and Chill ATES Applications by Suitability Cut-0ffs 


\subsection{POTENTIAL ENERGY SAVINGS FROM ATES}

The total energy savings potential from ATES applications is the product of the following: 1) the proportion of U.S. land area with suitable aquifers, 2) the proportion of economically feasible ATES locations (based on the different megawatt ranges), and 3 ) the total U.S. energy consumption for space heating/cooling and process heat.

The total energy consumption for space heating/cooling and process heating was estimated by summing the total national residential and commercial space heating (U.S. Department of Energy 1987) and adding it to process heat consumption. The process heat was calculated by using the proportion of electrical energy used for process heat in 1984 (Resource Dynamics Corporation 1986), multiplying it by the total electrical energy consumption (Energy Information Administration 1985), and then summing this with the total industrial consumption (Energy Information Administration 1985) for gas, liquid propane gas, and $0 i 1 /$ kerosene (assumed fuels are used for process heat only).

Because chill ATES does not demonstrate any economic feasibility above $10 \mathrm{MW}$, the expected energy savings using chill storage was not calculated. The energy savings for small aquifer-based systems was also excluded from the final calculations because small aquifers are limited to a flow velocity of approximately $\leq 500 \mathrm{gpm}$, which is below the $675-\mathrm{gpm}$ flow necessary for a $10-\mathrm{MW}$ ATES system (see appendix). The 10-MW level is often considered to be the minimum for a cost-effective ATES system.

The results in Figure 6.1 indicate the total energy savings for heat ATES systems in the U.S. for the different megawatt ranges. As shown in Figure 6.1, the potential energy savings range from $14.88 \%$ to $2.38 \%$ of total energy consumption. Because the cost-effective limits of ATES do not allow for the $<10-M W$ range, the most optimistic long-term savings possible are approximately $10 \%$, or about 8 quads of the total energy consumption in the nation. Approximately $3 \%$ to $5 \%$ (or about 3 to 4 quads) of energy is estimated as the shortterm savings possible from ATES. 


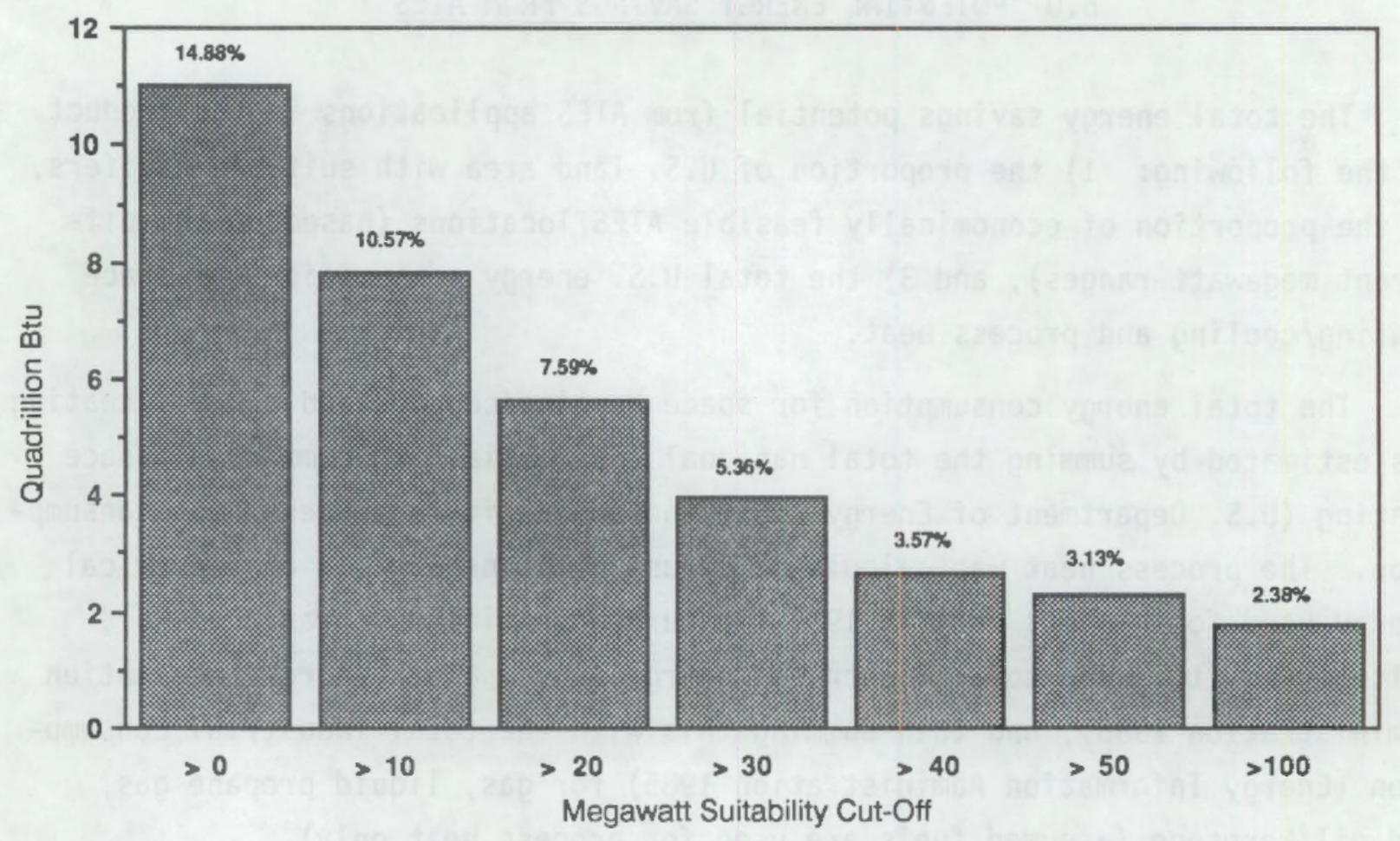

\section{FIGURE 6.1. Potential Energy Savings from ATES}

In the past, ATES applications have been viewed as a means of supplying both cost-effective heat or chill energy to end users. However, another major finding of this study was that chill storage did not display any market potential above the 10-MW level, which is typically viewed as the minimum for a cost-effective ATES heat or chill system. The implication of this finding is that large chill ATES systems will not significantly impact the U.S. energy consumption. However, this study does not address the application of chill ATES to specific sites that are uniquely suited for small-scale ATES systems. For that reason, the markets for chill ATES systems most likely would be suited for large, single site commercial or industrial buildings (e.g., wine cooling).

Currently, the reasonably acceptable level for short-range heat ATES application estimates are those found above the 30- to 40-MW levels because these levels have the most attractive short-term economies of scale. The energy savings from these levels are approximately 3 to 4 quads of energy or about $3 \%$ to $5 \%$ of the total energy consumed in the nation. 


\subsection{ATES MARKET DENSITY CHARACTERIZATION}

Additional analysis was performed on the stratification matrix to determine promising entry target markets for this technology.

Table 7.1 shows that the factors available for the analysis are individual stratifer cells, consumption ranges, and the economic feasibility percentages. By observing economic feasibility proportion for each consumption range in the top four cells you can see they are considerably higher than those in the bottom two cells. It is because of this that the most lucrative markets for heat ATES systems are those with employment population densities above 2000 employees per square mile. This includes about 1500 zip codes or approximately $4 \%$ of the total zip codes in the U.S.

The informal analysis of the economic feasibility by stratified cell demonstrates that the ATES markets with the most potential are found in those area's with greater than 2000 employment per square mile. Subsequently the focus of future studies should be directed at these markets because they demonstrate the greatest return. 
TABLE 7.1. The Proportion of Heat ATES Systems of Various Megawatt Sizes that are Economically Feasible at Different Residential Population Densities

\begin{tabular}{|c|c|c|c|c|}
\hline & & & Resi & \\
\hline & & $>6500$ & & $\leq 6500$ \\
\hline & & $>10 \mathrm{MW}$ & $77 \%$ & $73 \%$ \\
\hline & & $>20 \mathrm{MW}$ & $57 \%$ & $57 \%$ \\
\hline & $>6500$ & $>30 \mathrm{MW}$ & $37 \%$ & $43 \%$ \\
\hline & & $>40 \mathrm{MW}$ & $20 \%$ & $30 \%$ \\
\hline & & $>50 \mathrm{MW}$ & $17 \%$ & $17 \%$ \\
\hline & & $>100 \mathrm{MW}$ & $7 \%$ & $10 \%$ \\
\hline $\begin{array}{l}\text { Employment } \\
\text { density }\end{array}$ & & $>10 \mathrm{MW}$ & $80 \%$ & $77 \%$ \\
\hline & & $>20 \mathrm{MW}$ & $50 \%$ & $60 \%$ \\
\hline & $<6500$ & $>30 \mathrm{MW}$ & $33 \%$ & $47 \%$ \\
\hline & and & $>40 \mathrm{MW}$ & $33 \%$ & $33^{\circ}$ \\
\hline & $>2000$ & $>50 \mathrm{MW}$ & $30 \%$ & $33 \%$ \\
\hline & & $>100 \mathrm{MW}$ & $27 \%$ & $30 \%$ \\
\hline & & $>10 \mathrm{MW}$ & $53 \%$ & $10 \%$ \\
\hline & & $>20 \mathrm{MW}$ & $37 \%$ & $3 \%$ \\
\hline & & $>30 \mathrm{MW}$ & $27 \%$ & $3 \%$ \\
\hline & $<2000$ & $>40 \mathrm{MW}$ & $7 \%$ & $3 \%$ \\
\hline & & $>50 \mathrm{MW}$ & $7 \%$ & $3 \%$ \\
\hline & & $>100 \mathrm{MW}$ & $7 \%$ & $3 \%$ \\
\hline
\end{tabular}




\subsection{ATES ENERGY USER CHARACTERIZATION}

Further analysis was conducted to determine which end-use sectors will provide the greatest short-term energy savings. This analysis assumed that larger-sized ATES systems will be economically feasible in the short term. The results of this analysis are intended to impact research and development by directing expenditures to those sectors that offer the greatest short-term energy savings.

Residential, industrial, and commercial sector energy consumption was calculated for each of the megawatt ranges being studied. Each sector's consumption was calculated by summing the actual energy consumption by each enduse sector for zip code areas whose total heat energy consumption fell within the various megawatt ranges being studied (i.e., $>0$ and $<10,>10$ and $<20,>20$ and $<30,>30$ and $<40,>40$ and $<50,>50$ and $<100$, and $>100$ ). The total energy consumption for each end-use sector within the megawatt ranges was then converted to a percentage. The results of this analysis are summarized in Figure 8.1. Based on these results, it appears that the industrial sector is the primary consumer of energy in larger-sized ATES systems.

Additional analysis was conducted to determine the number of industrial energy users included in zip code areas that can support larger-sized ATES systems. This analysis indicated that an average of 9.97 high energy consuming plants are located in zip code areas that consume greater than $50 \mathrm{MW}$ of heat energy.

The results of these analyses indicate that the industrial sector should receive the primary research and development focus. This is because the industrial sector represents the largest user of process heat in larger-sized ATES systems. Further, this sector is attactive because of the small number of plants located in zip code areas with high energy consumption. 


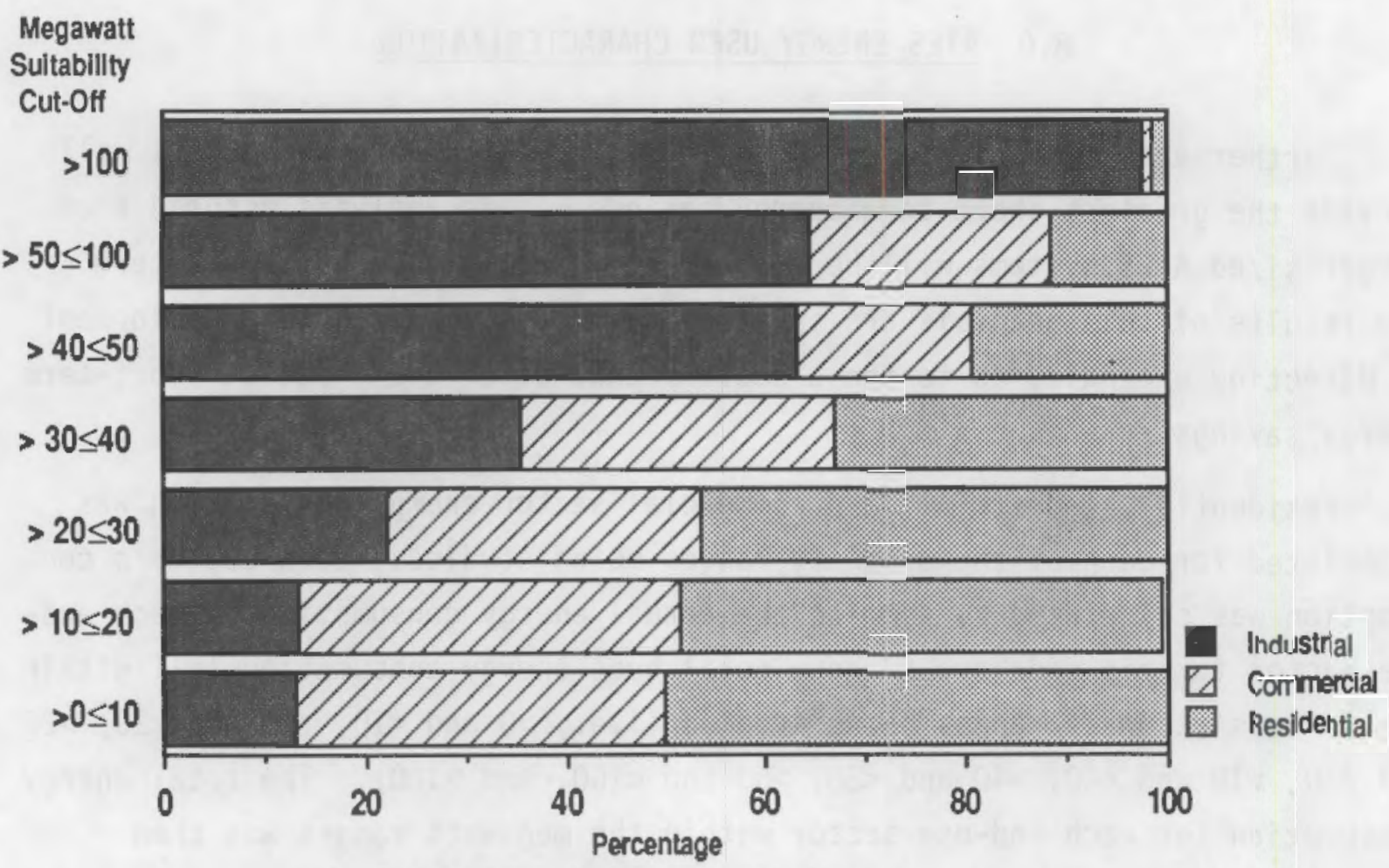

Potentlal Energy Savings by End-Use Sector

FIGURE 8.1. Heat Energy Savings by End Use 


\subsection{WASTE HEAT ENERGY SOURCES FOR ATES}

Aquifer thermal energy storage system operation is dependent on the availability of a heat source. An important issue is whether sufficient waste heat may already be available from existing industrial processes to meet energy user needs or whether supplemental sources, such as cogeneration or refuse burning, must be added to an ATES system to meet energy user needs.

The availability of waste heat energy can be calculated using a method similar to that used for estimating the consumption of process heat. Industrial process waste heat was estimated from a list of individual SIC codes within each zip code area. Industrial process waste energy was calculated as the percentage of firms from an SIC code (on a national basis) located within a zip code area multiplied by that SIC code's yearly total national waste process heat. (a) These values were then summed to find the total energy available for storage in each zip code area.

The next step was to sum separately the total consumption and waste for each of the zip code areas in which consumption falls into the following categories: $>10$ and $\leq 20 ;>20$ and $\leq 30 ;>30$ and $\leq 40 ;>40$ and $\leq 50 ;>50$ and $\leq 100$; and $>100 \mathrm{MW}$. The total consumption and waste values were then averaged by dividing these values by the number of zip code areas for each group whose consumption values fell into one of the ranges. The waste heat averages for each range were then multiplied by $66 \%$ to adjust for the loss of energy associated with the handling of the energy while transferring it to an ATES system and from storage (Reilly, Brown, and Huber 1981). With this adjustment, the average consumption can be compared to the adjusted waste energy available for each of the ranges.

The results of these calculations, shown in Figure 9.1, show that all but one range has an average supply of waste heat energy that exceeds the average consumption of heat energy. The only range that failed to demonstate

(a) Table A.2 includes industrial process sources and uses of heat by SIC codes. 


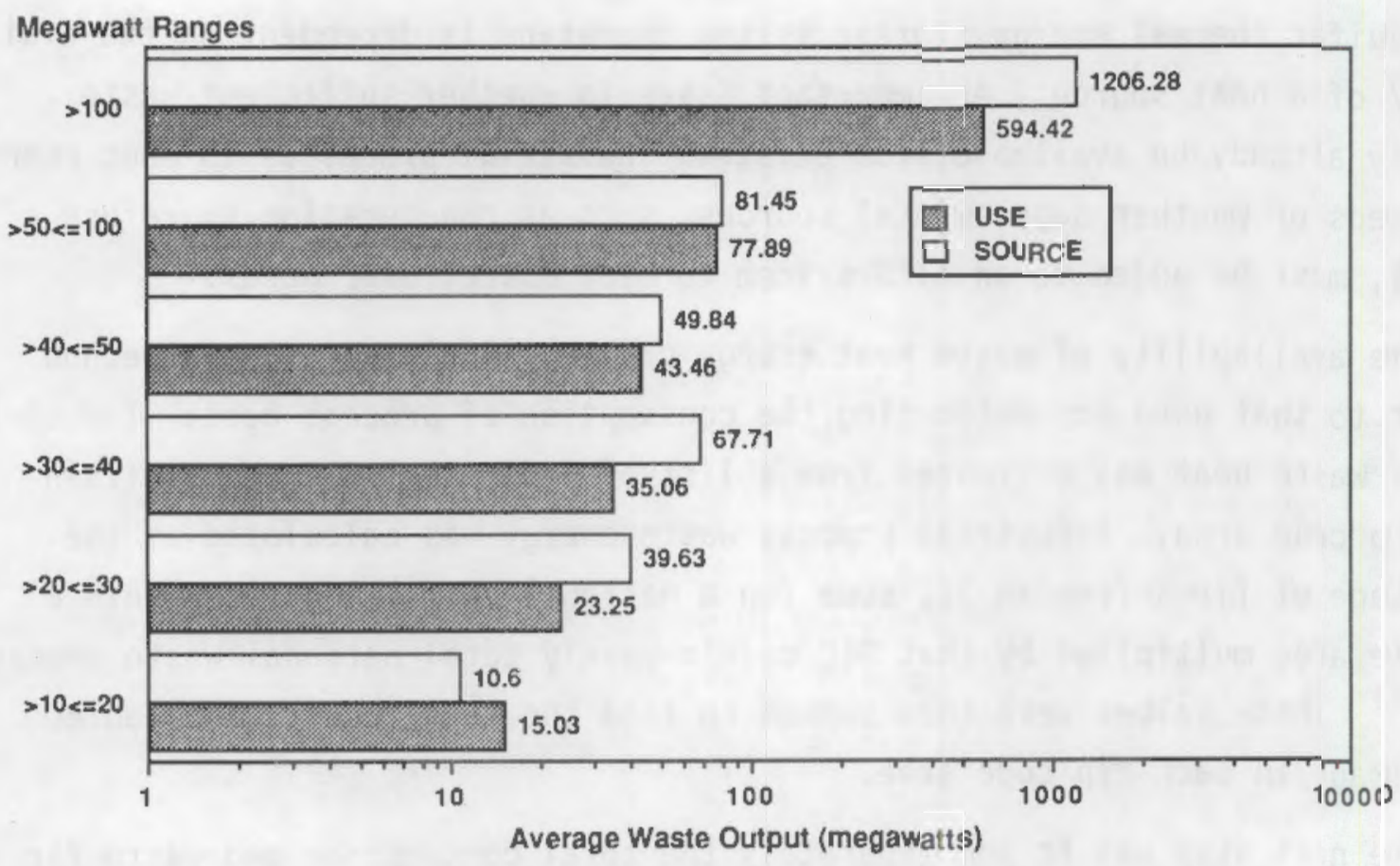

FIGURE 9.1. Waste Heat Energy Supply and Use

the ability to supply total consumption requirements was the 10 - to $20-\mathrm{MW}$ range. This indicates that ATES can virtually be run on waste energy that is already available in a proximity suitable for ATES applications. These results imply that savings from ATES systems can legitimately be termed "energy savings," because additional sources of heat are not required. 


\section{REFERENCES}

Brown, D. R. 1983. Aquifer Thermal Energy Storage Costs with a Seasonal Chill Source. PNL-4587, Pacific Northwest Laboratory, Richland, Washington.

Century West Engineering Corporation. 1981. Regional Assessment of Aquifers for Thermal Energy Storage. PNL-3955, Vol. 1-3, Pacific Northwest Laboratory, Richland, Washington.

Energy Information Administration. 1985. Residential Energy Consumption Survey: Consumption and Expenditures. Energy Information Administration, U.S. Department of Energy, Washington, D.C.

Energy Information Administration. 1983. Nonresidential Buildings Energy Consumption Survey: Commercial Buildings Consumption and Expenditures. Energy Information Administration, U.S. Department of Energy, Washington, D.C.

Energy Information Administration. 1979. Nonresidential Buildings Energy Consumption Survey: Commercial Buildings Consumption and Expenditures. Energy Information Administration, U.S. Department of Energy, Washington, D.C.

Latta, R. B. 1983. Residential Energy Consumption Survey: Regression Analysis of Energy Consumption by End Use. Energy Information Administration, U.S. Department of Energy, Washington, DC.

Meyer, C. F., and W. Hauz. 1980. Guidelines for Conceptual Design and Evaluation of Aquifer Thermal Energy Storage. PNL-3581, Pacific Northwest Laboratory, Richland, Washington.

Reilly, R. W., D. R. Brown, and H. D. Huber. 1981. Aquifer Thermal Energy Storage Costs with a Seasonal Heat Source. PNL $-413 \overline{5}$, Pacific Northwest Laboratory, Richland, Washington.

Resource Dynamics Corporation. 1986. Electrotechnology Reference Guide. EPRI EM-4527, Prepared for Electric Power Research Institute, Palo ATto, California.

U. S. Department of Commerce. 1986. Statistical Abstract of the United States. 106th Edition.

U.S. Department of Energy. 1987. Analysis and Technology Transfer Annual Report - 1986. Washington, D.C. 

APPENDIX

SUPPLEMENTAL DATA 


\section{APPENDIX}

\section{SUPPLEMENTAL DATA}

Table A.1 shows the final results found for the sample of 50 zip codes chosen to determine the proportion of suitable aquifers in the U.S. for ATES applications. The data in Table A.1 are sorted by region; suitability of each zip code area is indicated in terms of system storage type and size.

IABLE A.1. Aquifer Suitability

\begin{tabular}{|c|c|c|c|c|}
\hline City & State & County & Region & ATES Potential \\
\hline Curlew & WA & Ferry & 1 & Unsuitable \\
\hline Fresno & $\mathrm{CA}$ & Fresno & 2 & sc sl sh $1 \mathrm{c} 11 \mathrm{lh}^{(\mathrm{a})}$ \\
\hline Portland & OR & Multnomah & 2 & sc $\mathrm{sl}$ \\
\hline Cornville & $A Z$ & Yavapai & 4 & sc sl sh \\
\hline Boelus & NE & Howard & 5 & sc sl sh ic $11 \mathrm{lh}$ \\
\hline Marble Rock & IA & Floyd & 6 & sc sl sh lc $11 \mathrm{lh}$ \\
\hline Peru & IA & Madison & 6 & sc sl sh lc $11 \mathrm{lh}$ \\
\hline Lewistown & IL & Fulton & 6 & sc sl sh lc 11 ih \\
\hline West 01 ive & MI & Ottawa & 6 & sc sl \\
\hline St. Joseph & MO & Buchanan & 6 & sc sl sh lc 11 ih \\
\hline Pisek & ND & Walsh & 6 & sc sl sh \\
\hline Columbus & $\mathrm{OH}$ & Franklin & 6 & sc sl sh ic 11 ih \\
\hline Faulkton & SD & Faulk & 6 & sc sl sh Ic $11 \mathrm{lh}$ \\
\hline Hector & $A R$ & Pope & 7 & sc sl sh ic 11 ih \\
\hline Blaine & KY & Lawrence & 7 & sc sl sh \\
\hline Belfield & ND & Stark & 7 & sc sl sh ic $11 \mathrm{lh}$ \\
\hline San Jose & NM & San Miguel & 7 & Unsuitable \\
\hline Venetia & $P A$ & Washington & 7 & sc sl sh \\
\hline Okaton & SD & Jones & 7 & sc sl sh ic 11 ih \\
\hline Sand Creek & WI & Dunn & 7 & sc sl \\
\hline Luray & VA & Page & 8 & Unsuitable \\
\hline
\end{tabular}

(a) $\begin{gathered}s= \\ \text { héat }\end{gathered}$ A.1 
TABLE A.1. (contd)

\begin{tabular}{|c|c|c|c|c|}
\hline City & State & County & Region & ATES Potential \\
\hline Bandytown & WV & Boone & 8 & Unsuitable \\
\hline Clothier & WV & Logan & 8 & Unsuitable \\
\hline Shenandoah Jct. & WV & Jefferson & 8 & Unsuitable \\
\hline Wende 11 & NH & Sullivan & 9 & Unsuitable \\
\hline Balmat & NY & St. Lawrence & 9 & Unsuitable \\
\hline Chenango Bridge & NY & Broome & 9 & sc sl sh(a) \\
\hline Palmerton & PA & Carbon & 9 & Unsuitable \\
\hline Shady Grove & $\mathrm{PA}$ & Franklin & 9 & Unsuitable \\
\hline Billingsley & AL & Autauga & 10 & sc sl sh lc $11 \mathrm{lh}$ \\
\hline Shelby & AL & Shelby & 10 & sc sl sh \\
\hline Garner & AR & White & 10 & sc sl sh \\
\hline Ellendale & $\mathrm{DE}$ & Sussex & 10 & $5 c$ si sh lc $11 \mathrm{lh}$ \\
\hline Avon Park & $\mathrm{FL}$ & Highlands & 10 & Unsuitable \\
\hline Delray Beach & $\mathrm{FL}$ & Palm Beach & 10 & Unsuitable \\
\hline Miami & $\mathrm{FL}$ & Dade & 10 & Unsuitable \\
\hline Punta Gorda & $\mathrm{FL}$ & Charlotte & 10 & sc sl \\
\hline Cusetta & GA & Chattahoochee & 10 & sc sl sh lc 11 ih \\
\hline Hyattsville & MD & Prince George's & 10 & sc sl sh lc $11 \mathrm{lh}$ \\
\hline North Beach & MD & Calvert & 10 & sc sl sh ic 11 in \\
\hline okolona & MS & Chickasaw & 10 & sc si sh ic 11 in \\
\hline Redwood & MS & Warren & 10 & sc sl sh ic $11 \mathrm{th}$ \\
\hline Barnegat Light & NJ & Ocean & 10 & sc sl sh lc 11 in \\
\hline Mauricetown & NJ & Cumberland & 10 & sc sl sh ic $11 \mathrm{lh}$ \\
\hline Neshanic Station & NJ & Somerset & 10 & sc sl sh \\
\hline Somerville & NJ & Somerset & 10 & sc sl sh \\
\hline Staten IsI and & NY & Richmond & 10 & sc sl sh lc 11 ih \\
\hline Onemo & VA & Mathews & 10 & sc sl sh ic $11 \mathrm{lh}$ \\
\hline Cordova & AK & Valdez-Cordova & 12 & sc sl sh \\
\hline Nikolski & AK & Aleutian Islands & 12 & Unsuitable \\
\hline
\end{tabular}

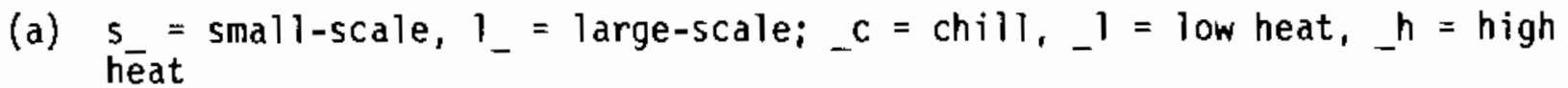




\section{A.1 AQUIFER CRITERIA}

The matrices shown in Tables A.2 and A.3 are the criteria used for the determination of suitable aquifers used for the sample of $50 \mathrm{zip}$ codes. The first is for the heat ATES system and the second is for the chill applications of ATES systems.

\section{A.2 CALCULATION OF SUITABILITY OF SMALL AQUIFERS}

The calculations used to determine if a small aquifers are suitable for a 10-MW system are presented below.

One calorie (large) equals the amount of heat required to raise 1 liter of water $1^{\circ} \mathrm{C}$.

$1 \mathrm{MW}=1,000 \mathrm{~kW}$

$1 \mathrm{~g}=3.785 \mathrm{l}$

$1 \mathrm{gpm} / \mathrm{min} 01^{\circ} \mathrm{C}_{-} \mathrm{T}=3.785$ calories $/$ min $=0.264 \mathrm{~kW}$

$$
\mathrm{kW}=Q \times \underline{-} \mathrm{T} \times \mathrm{Eff} \times 0.264
$$

where $Q=$ flow in gpm

$$
\begin{aligned}
\hat{\imath} T & =\text { temperature difference in }{ }^{\circ} \mathrm{C} \\
\text { Eff } & =\text { heat exchange efficiency in percent. }
\end{aligned}
$$

Assume that an ATES system has groundwater in storage having a temperature of $100^{\circ} \mathrm{C}$. A reasonable estimate for the recovery process would be an extraction of $80^{\circ} \mathrm{C}$ with an efficiency of $70 \%$. Compute the flow rate $(Q)$ necessary for a $10-M W$ system.

$$
\begin{aligned}
\mathrm{kW} & =Q \times{ }_{-}^{\wedge} \times \mathrm{Eff} \times 0.264 \\
10,000 & =Q \times 80^{\circ} \mathrm{C} \times 0.70 \times 0.264 \\
Q & =676 \mathrm{gpm} \text { for } 10 \mathrm{MW} .
\end{aligned}
$$


TABLE A.2. Large System Limiting Guidelines

\begin{tabular}{|c|c|c|c|c|c|c|c|c|c|c|}
\hline \multirow[b]{2}{*}{$\begin{array}{c}\text { Aquifer } \\
\text { Characteristics }\end{array}$} & \multirow[b]{2}{*}{ Unit } & \multicolumn{3}{|c|}{ Chill } & \multicolumn{3}{|c|}{ Low Temperature } & \multicolumn{3}{|c|}{ High Temperature } \\
\hline & & Unsuitable & Marginal & Suitable & Unsuitable & Marginal & Suitable & Unsuitable & Marginal & Suitable \\
\hline Depth & $\mathrm{ft}$ & $<20$ & -- & $>20$ & $<20$ & - & $>20$ & $<20$ & -- & $\begin{array}{l}\text { Sufficient } \\
\text { hydrostatic } \\
\text { pressure }\end{array}$ \\
\hline Thickness & $\mathrm{ft}$ & $<100$ & -- & $\geq 100$ & $<100$ & -- & $\geq 100$ & $<100$ & - & $\geq 100$ \\
\hline $\begin{array}{l}\text { Typical well } \\
\text { yield }\end{array}$ & gpm & $<500$ & -- & $>500$ & $<500$ & -- & $>500$ & $<500$ & - & $>500$ \\
\hline Transmissivity & gpd/ & $<1000$ & -- & $\begin{array}{l}>1000 \\
\text { (a) }\end{array}$ & $<1000$ & -- & $\begin{array}{l}>1000 \\
\text { (a) }\end{array}$ & $<1000$ & $\cdots$ & $>1000$ \\
\hline Porosity & $\%$ & $<5$ & $>5<15$ & $>15$ & $<5$ & $>5<15$ & $>15$ & $<5$ & $>5<15$ & $>15$ \\
\hline
\end{tabular}


IABLE A.3. Small System Limiting Guidelines

\begin{tabular}{|c|c|c|c|c|c|c|c|c|c|c|}
\hline \multirow{2}{*}{$\begin{array}{c}\text { Aquifer } \\
\text { Characteristics }\end{array}$} & \multirow[b]{2}{*}{$\underline{\text { Unit }}$} & \multicolumn{3}{|c|}{ Chill } & \multicolumn{3}{|c|}{ Low Temperature } & \multicolumn{3}{|c|}{ High Temperature } \\
\hline & & Unsuitable & Marginal & Suitable & Unsuitable & Marginal & Suitable & Unsuitable & Marginal & Suitable \\
\hline Depth & $\mathrm{ft}$ & $<20$ & -- & $>20$ & $<20$ & -- & $>20$ & $<20$ & -- & $\begin{array}{l}\text { Sufficient } \\
\text { hydrostatic } \\
\text { pressure }\end{array}$ \\
\hline Thickness & $f t$ & $<20$ & $>20<25$ & $>25<500$ & $<20$ & -- & $>25<100$ & $<20$ & $>20<25$ & $>50<100$ \\
\hline $\begin{array}{l}\text { Typical well } \\
\text { yield }\end{array}$ & $\mathrm{gpm}$ & $<50$ & -- & $>50<500$ & $<50$ & $\cdots$ & $>50<500$ & $<50$ & -- & $>50<500$ \\
\hline Transmissivity & $\underset{f t}{g p d /}$ & $\begin{array}{l}<1000 \text { or } \\
>20,000\end{array}$ & -- & $\begin{array}{c}>1000 \text { or } \\
<20,000 \\
\text { (a) }\end{array}$ & $\begin{array}{l}<1000 \text { or } \\
>20,000\end{array}$ & -- & $\begin{array}{c}>1000 \text { or } \\
<20,000 \\
\text { (a) }\end{array}$ & $\begin{array}{l}<1000 \text { or } \\
>20,000\end{array}$ & -- & $\begin{array}{c}>1000 \text { or } \\
<20,000 \\
\text { (a) }\end{array}$ \\
\hline Porosity & $q_{6}$ & $<5$ & $>5<15$ & $>15$ & $<5$ & $>5<15$ & $>15$ & $<5$ & $>5<15$ & $>15$ \\
\hline
\end{tabular}

(a) Values near 20,000 for Transmissivity are desirable. 


\section{A.3 INDUSTRIAL SOURCE AND USE OF ENERGY}

Table A.4 lists 61 industries by SIC codes that consume $80 \%$ of the energy. Values given are for both waste energy available for storage and energy consumption for process heat between $26.7^{\circ} \mathrm{C}$ and $204.7^{\circ} \mathrm{C}\left(80^{\circ} \mathrm{F}\right.$ and $\left.400^{\circ} \mathrm{F}\right)$. These values were used for calculating the process heat consumption within each zip code area sampled and for calculating the waste heat availability in each zip code area. 
IABLE A.4. Aquifer Thermal Energy Storage Annual Energy Input/Usage

Industry
Description

Food

Textiles

Lumber

$\begin{array}{cc} & 2411 \\ & 2421 \\ & 2499 \\ \text { Pulp/paper } & 26 \\ & 2611 \\ & 2621 \\ & 2631 \\ & 2653 \\ & 2661 \\ \text { Chemicals } & 28 \\ & 2812 \\ & 2813 \\ & 2816 \\ & 2819 \\ & 2821 \\ & 2822 \\ & 2823 \\ & 2824 \\ 2834 \\ 2865 \\ 2869 \\ 2873 \\ 2874 \\ 2899\end{array}$

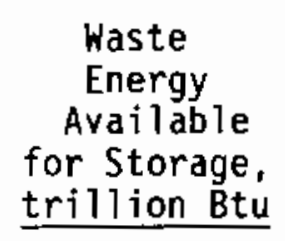

48.8

21.4

16.5

37.2

7.1

29.2

53.2

36.2

41.9

34.5

46.8

0.1
144.7
4.1

152.9

533.0

477.8

2.5

18.2

249.0

87.0

24.5

98.3

42.9

29.0

25.4

148.9

6.2

137.6

239.1

247.2

62.7

3.1
Industry Demand for

$80^{\circ} \mathrm{F}$ to $400^{\circ} \mathrm{F}$ Heat,

trillion Btu

36.6

7.9

16.4

23.1

1.8

26.3

34.7

40.9

23.9

22.5

32.0

148.4

1.8

115.2

419.1

342.7

3.5

14.9

151.2

34.8

12.0

105.1

11.2

8.7

25.4

32.0

4.4

94.0

46.8

25.7

22.6

1.6

A. 7 
TABLE A.4. (contd)

\begin{tabular}{|c|c|c|c|}
\hline $\begin{array}{l}\text { Industry } \\
\text { Description }\end{array}$ & $\begin{array}{l}\text { SIC } \\
\text { Code }\end{array}$ & $\begin{array}{r}\text { Available } \\
\text { for Storage, } \\
\text { trillion Btu } \\
\end{array}$ & $\begin{array}{l}80^{\circ} \mathrm{F} \text { to } 400^{\circ} \mathrm{H} \\
\text { Heat. } \\
\text { trillion Btu } \\
\end{array}$ \\
\hline Petroleum & $\begin{array}{l}29 \\
2911 \\
2951\end{array}$ & $\begin{array}{r}1880.1 \\
7.2\end{array}$ & $\begin{array}{l}2.3 \\
--\end{array}$ \\
\hline Rubber & $\begin{array}{l}30 \\
3011 \\
3069 \\
3079\end{array}$ & $\begin{array}{r}9.3 \\
30.1 \\
35.6\end{array}$ & $\begin{array}{l}25.5 \\
39.4 \\
-\end{array}$ \\
\hline $\begin{array}{l}\text { Stone, clay } \\
\text { and glass }\end{array}$ & $\begin{array}{r}32 \\
3211 \\
3221 \\
3229 \\
3241 \\
3251 \\
3273 \\
3274 \\
3275 \\
3296\end{array}$ & $\begin{array}{r}13.7 \\
55.9 \\
14.4 \\
179.1 \\
32.9 \\
1.2 \\
27.2 \\
27.3 \\
32.1\end{array}$ & $\begin{array}{l}-- \\
-- \\
-- \\
-- \\
-- \\
-- \\
-- \\
-- \\
7.5\end{array}$ \\
\hline $\begin{array}{l}\text { Primary } \\
\text { metals }\end{array}$ & $\begin{array}{r}33 \\
3321 \\
3313 \\
3321 \\
3331 \\
3334 \\
3341 \\
3353 \\
3362\end{array}$ & $\begin{array}{r}789.1 \\
16.5 \\
117.7 \\
46.5 \\
89.6 \\
5.9 \\
21.8 \\
32.8\end{array}$ & $\begin{array}{l}62.5 \\
-- \\
-- \\
1.1 \\
-= \\
-- \\
-- \\
-=\end{array}$ \\
\hline Machinery & $\begin{array}{r}35 \\
3523 \\
3531\end{array}$ & $\begin{array}{l}30.7 \\
32.3\end{array}$ & -- \\
\hline $\begin{array}{l}\text { Transportation } \\
\text { equipment }\end{array}$ & $\begin{array}{l}37 \\
3711 \\
3714\end{array}$ & $\begin{array}{l}44.4 \\
74.2\end{array}$ & -- \\
\hline Instruments & ${ }^{38} 3861$ & 4.0 & -- \\
\hline
\end{tabular}




\section{DISTRIBUTION}

No. of

Copies

\section{OFFSITE}

U.S. Department of Energy

Attn: K. Klein

Office of Energy Storage \& Dist.

Forrestal Bldg, CE-32 5E-036

Washington, DC 20585

U.S. Department of Energy

Attn: E. Reimers

Office of Energy Storage \& Dist.

Forrestal B1dg, CE-32 5E-036

Washington, DC 20585

10 DOE/Office of Scientific and

Technical Information

Argonne National Laboratory

Solar Thermal Storage Program

Attn: A. Gorsky

Building 362

9700 S. Cass Avenue

Argonne, IL 60439

Auburn University

Attn: F. J. Molz

School of Engineering

Auburn, AL 36830

Brown and Caldwell

Attn: E. Knipe

150 Arroya Parkway

Pasadena, CA 91109

District Heating Development Co.

Attn: H. Jaehne

$76 \mathrm{~W}$. Kellogg Blvd.

St. Pau 1, MN 55102

GeoTrans Inc.

Attn: J. W. Mercer

PO Box 2550

Reston, VA 22090
No. of

Copies

Walter Hauz

4520 Via Vistosa

Santa Barbara, CA 93110

Lawrence 8erkeley Laboratory

Attn: C-F. Tsang

University of California

Bldg. 90, Room 1012-H

1 Cyclotron Road

Berkeley, CA 94720

Charles F. Meyer

1141 Cima Linda Lane

Santa Barbara, CA 93108

Minnesota Geological Survey

Attn: M. Hoyer

2642 University Avenue

St. Paul, MN 55114

Minnesota Geological Survey

Attn: J. Splettstoesser

2642 University Avenue

St. Paul, MN 55114

New York State Energy

Research \& Development

Agency

Attn: G. Walmet

Rockefeller Plaza

Albany, NY 12223

Oak Ridge National Laboratory

Attn: M. Taylor

Building 9204-1, MS 8045

Y-12 Plant, Box 2009

0ak Ridge, TN 37831-8045

Oak Ridge National Laboratory

Attn: J. Tomlinson

Building 9204-1, MS 8045

Y-12 Plant, Box 2009

Oak Ridge, TN 37831-8045 
No. of

Copies

Office of Congressman

Sid Morrison

Attn: Kevin Billings,

Legislative Asst.

1330 Longworth Bldg.

Washington, DC 20515

office of Congressman

Tom Bevil

2302 Rayburn Bldg.

Washington, DC 20515

Oregon State University

Attn: S. W. Childs

Dept. of Soil Science

Corvallis, OR 97331

Resource Efficiency, Inc.

Attn: M. Spurr

340 Daly Street

St. Paul, MN 55102

Rocket Research Company

Attn: D. D. Huxtable,

Director Energy R\&D

York Center

Redmond, WA 98052

Rocket Research Company

Attn: L. B. Katter

York Center

Redmond, WA 98052

Sandia National Laboratories

Technical Library

Division 3141

Albuquerque, NM 87185

University of Alabama

Attn: E. Brett

School of Mines and Energy Development

Box 6282

University, AL 35486
No. of

Copies

University of Massachusetts at Amherst

Attn: 0 . Breger

Dept. of Mechanical Eng.

Eng. Laboratory Bldg.

Amherst, MA 01003

University of Massachusetts at Amherst

Attn: J. E. Sunderland

Dept. of Mechanical Eng.

Eng. Laboratory Bldg.

Amherst, MA 01003

University of Minnesota

Attn: R. L. Sterling

Underground Space Center

Dept. of Civil and Mineral Eng.

790 Civil and Mineral Eng. Bldg.

Minneapolis, MN 55455

US Army Corps of Engineers

Attn: C. W. Sohn

Construction Engineering

Research Laboratory

PO Box 4005

Champaign, IL 61820

US Department of Interior

Attn: Natural Resources

Library

Serials Branch (G/E)

Washington, DC 20240

Wehran Engineering

Attn: R. Miller

666 E. Main St.

P0 Box 2006

Middletown, NY 10940

Wikle and Associates

Attn: D. Wilke

38 Roosevelt Avenue

Glen Head, NY 11545 
No. of

Copies

\section{FOREIGN}

Bengt Hidemark Gosta Danielson Arkitekter SAR

Attn: A. Boysen

Jarntorget 78

S-11 29 Stockholm

Sweden

Commission of European

Communities

Attn: P. Zegers

DG XII, E3

200 Weststraat

Brussels, Belgium

Heidemij Adviesbureau

Attn: A. Snijders

P0 Box 264

NL-6800 AG Arnhem

The Netherlands

I.E.N.E.R.

EPF-Ecublens

Attn: B. Saugy

1015 Lausanne

Switzerland

Institut fur Kernenergetik und Energiesystem

Attn: D. Steiner

Universitat Stuttgart

7000 Stuttgart 80

West Germany

KFA Julich

Projektleitung Energieforschung

Attn: F. J. Friedrich

P0 Box 1913

D-5170 Julich

West Germany

KFA Julich, PLE

Attn: V. Lottner

PO Box 1913

D-5170 Julich

West Germany
No. of

Copies
Laboratory for Energetics

Attn: B. Qvale

Technical University of Denmark

DK-2800 Lyngby

Denmark

Management Office for Energy Research PEO

Attn: K. Joon

P. 0. Box 8242

NL-Utrecht

The Netherlands

B. Mathey

Consuiting-Engineers Ltd. 2205 Montezillon-Neuchatel

Switzerland

Ministry of Trade and Industry

Attn: P. Vainio

Energy Department

POHJ Makasunikatu 6

SF-00130 Helsinki 13

Finland

Public Works of Canada

Attn: E. L. Morofsky

C456 Sir Charles Tupper Bldg.

Riverside $\mathrm{Dr}$. and Heron Rd.

Ottawa, Ontario

K1A 0M2 Canada

Riso National Laboratory

Attn: P. L. Christensen

DK-4000 Roskilde

Denmark

Swedish Council for Building Research

Attn: S-E. Lundin

St. Goransgatan 66

S-112 33 Stockholm

Sweden 
No. of

Copies

Swedish Council for Building Research

Attn: W. Raldow

St. Goransgatan 66

S-112 33 Stockholm

Sweden

Swiss Federal Energy office

Attn: A. Fehr

$\mathrm{CH}-3003$ Berne

Switzerland

Universitat Stuttgart

Attn: Rudolf Giebe

Pfaffenwaldring 6

7000 Stuttgart 80

West Germany
No. of

Copies

ONSITE

DOE Richland Operations office

J. J. Sutey

29 Pacific Northwest Laboratory

M. R. Anderson (2)

R. C. Adams

J. M. Bates

D. R. Brown

J. A. Dirks

M. K. Drost

K. Drumheller

C. H. Imhoff

L. D. Kannberg (10)

G. E. Spanner

R. 0. Weijo (2)

T. A. Williams

Technical Report Files (5)

Publishing Coordination (2) 